\title{
The Principle Obedience to the Pragmatic Aspects in Javanese Humor Memes (An Effort to Explore Javanese Local Wisdom)
}

\author{
S Mulyani \\ \{siti_mulyani@uny.ac.id\} \\ Yogyakarta State University Yogyakarta, Indonesia
}

\begin{abstract}
This study aims to describe the principle obedience to pragmatic rules, particularly the Cooperative Principle and the Politeness Principle in Javanese humor meme discourses. The research design used in this study is descriptive with the research object of the principle obedience to the maxims in the Cooperative Principle and the Politeness Principle in Javanese humor meme discourses. Realizing the Javanese humor memes has been done in many different ways but viewed from the pragmatic aspect it is still obedient to the maxims in the Cooperative Principle as well as the Politeness Principle. Principle obedience to the maxims in the Cooperative Principle includes: too much contribution, accurate utterances with evidence, utterances using relevant comparison, and clear and orderly utterances. The meme utterance principle obedience to the Politeness Principle is manifested in the expressions which contain the utterances that are beneficial to others, the utterances that give others their own choices, the utterances that contain self-control, the utterances that contain praises to others' speech, the utterances that contain one's similarity to fireworks, the utterances that contain one's acceptance of others, and the utterances that contain congratulating expressions.
\end{abstract}

Keywords: principle obedience, pragmatic aspects. meme discourses, Javanese

\section{INTRODUCTION}

Using a language is a social activity which involves humans, such as the use of Javanese as a means of communication to convey a person's ideas and feeling to another person. The Javanese language is used among others as a medium for expressing humor. Expressing humor can be done through written media which can be accessed easily by other people, for example by expressing humor in the Internet [1]-[3]. One of the manifestations of Javanese written discourses which contain humor easily accessible through the Internet search can be found in the blog Mете Lиси Galau Bahasa Jawa. Listyorini mentions that a meme is a discourse in the form of pictures/photographs with certain writing [4]. The writing in a meme is the words of humorous expressions which are intended as innuendos [5]. Therefore, it can be said that a meme is a written discourse in the form of pictures with words containing innuendos. Through memes, people can covey humorous words which contain innuendos when those words are seriously thought of [6], [7]. 
Today's studies of memes on internet stay to the speech perspective and pragmatic. Some of them are memes as symbols [8]-[11], meme as humor [2], [4], [12], and memes as social and cultural products [6], [13]-[18]. Memes as communication have already studied, but still focus on meme structures and its existence on internet, not on the communication devices and components in memes [1], [7], [19]-[24].

Furthermore, it is said that the humor in the language aspect of Indonesian memes is realized in two aspects, namely the phonological aspect and semantic aspect. The most dominant phonological aspect is the repetition of sounds or in literature known as rhyme. Meanwhile, the most dominant semantic aspect is repetition, followed by the use of simile, metaphor, hyperbole, personification, syllogism, abbreviation, and proverbs. The study of Javanese memes is as interesting as that of the Indonesian ones.

The use of the Javanese language as a means of communication, including the use of Javanese in meme discourses is a social interaction using language which should be cooperative. The criteria of cooperative interaction processes refer to the Cooperative Principle and the Politeness Principle. Grice mentions that in the application of the Cooperative Principle, utterances should satisfy four maxims, i.e. maxim of quantity, maxim of quality, maxim of relevance, and maxim of manner [25]. Wijana [26] explains that the maxim of quantity requires that every speaker can give sufficient amount of information as needed by the interlocutor. The maxim of quality requires that the speaker should give a contribution which is true based on sufficient evidence. The maxim of relevance requires that the contribution given should be relevant with the topic being discussed. The maxim of manner requires that the contribution given is direct, clear, unambiguous, not wordy, and orderly.

Furthermore, it is explained that the Politeness Principle consists of the tact maxim, approbation maxim, generosity maxim, modesty maxim, agreement maxim, and sympathy maxim. The maxim of tact requires that the speaker should minimize the disadvantages of others or maximize the benefits of others. The maxim of approbation requires that the speaker should maximize his/her own disadvantages or minimize his/her own benefit. The maxim of generosity requires that the speaker should maximize the respect to others or minimize the blame on others. The maxim of modesty requires that the speaker should maximize selfdisrespect or minimize self-respect. The maxim of agreement requires that the speaker should maximize his/her agreement with others or minimize his/her disagreement with others. The maxim of sympathy requires that the speaker should maximize sympathy to others or minimize his/her antipathy to others.

Although the Javanese meme discourses are humorous discourses, when viewed from the pragmatic aspect, they are still discourses which are principle-obedient to the maxims in the Cooperative Principle and the Politeness Principle. This can be seen in the example below.

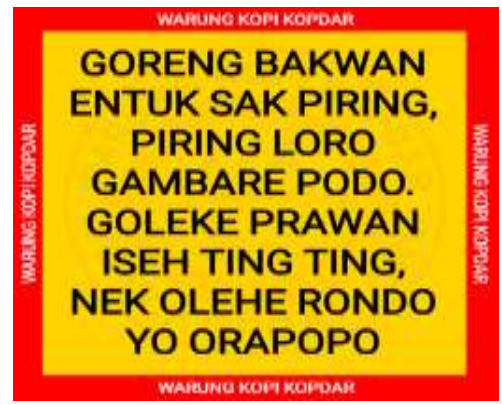

Figure 1. Meme with parikan (philosophical poem). Source: dpbbm.blogspot.com 
The discourse in the above humorous is in the form of parikan containing two sentences, each consisting of two clauses, as follows:

Goreng bakwan entuk sapiring, piring loro gambare podo / Golek prawan iseh ting-ting, nek olehe rondo yo ora popo.

(Get a plate of fried corn flitter; two plates have the same picture / Look for a virgin girl; getting a widow is okay, though.)

The content of the discourse is that a man is looking for a virgin girl, but having a widow will not be a problem to him. In terms of the Politeness Principle, the content of the discourse is the discourse which is principle obedient to the maxim of agreement, because it emphasizes the aspect of agreement with whatever experienced by the man although it does not satisfy his expectation. In this case, he is looking for a virgin girl, but having a widow is not a problem. The humor is expressed in the form of a poem containing the rhyme (a i) in the word bakwan and prawan, sapiring and ting-ting as well as the word podo (padha) and popo (papa). In relation to this, the question is: How is the principle obedience to the Cooperative Principle and the Politeness Principle expressed in discourse memes categorized as humor memes? This article describes the Javanese meme discourse's principle-obedience to the maxims in the Cooperative Principle and the Politeness Principle.

\section{RESEARCH METHOD}

The research design applied in this study is descriptive, with the aim of clarifying a phenomenon that is happening now. The source of the data is 75 humor memes in seven meme webs in the Internet, downloaded in May 2019. The instrument used includes the human instrument, and the software in the form of indicators/criteria of the maxims in the Cooperative Principle and the Politeness Principle as the theory used, as the reference of this study. The data were collected using the method of capturing and printing, the method of listening/reading carefully and noting. The data analysis used is the descriptive analysis. The validity used in this study is the content validity and semantic validity, while the reliability is the intra-rater reliability.

\section{RESULT AND DISCUSSION}

This part of this article presents the result of the analysis of the principle obedience to the maxims in the Cooperative Principle and the Politeness Principle of Javanese humor memes. Although memes as a means of communication consist of words and pictures categorized as humor memes, if they are related to the maxims in the Cooperative Principle, many memes are principle obedient to the maxims. The Cooperative Principle consists of four maxims, i.e. maxim of quantity, maxim of quality, maxim of relevance, and maxim of manner. The realization of the principle obedience is described below.

The maxim of quantity requires that every speaker should give sufficient contribution or as much contribution as required by the interlocutor. The discourse which is suitable with the maxim of quantity is not wordy but concise, which can be seen in the Javanese humor meme below. 


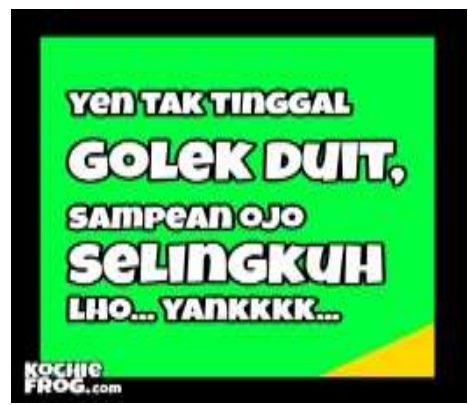

Figure 2. The meme which is principle obedient to the maxim of quantity. Source: betseyramagephotography.blogspot.com

In the above meme, it is written 'yen tak tinggal golek duit (dhuwit), sampayen ojo (aja) selingkuh lho.. yankkk...' (If I'm away looking for money and you are home alone, don't cheat me, honey.) The writer of this meme tells the people who have wives/husbands to be faithful whenever they are left alone at home and their spouses are away looking for a living. The message in the meme is expressed in a short and concise expression. Therefore, the text is a discourse which is principle obedient to the quantity maxim, because it gives the right amount of information as needed.

The maxim of quality requires that the speaker should give a contribution which is true based on sufficient evidence. The following is an example of the meme that meets the requirement for the maxim of quality.

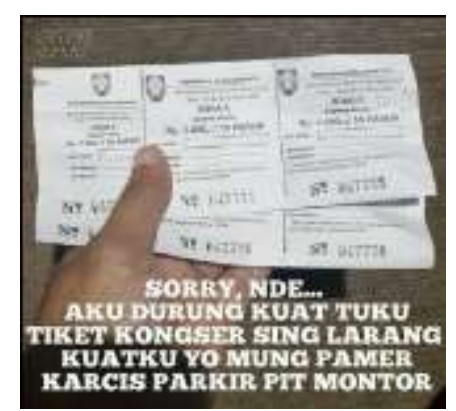

Figure 3. Meme suitable with the maxim of quality. Source: dagelanlucu.com

The above humor meme reads: "Sorry, nde...aku durung kuat tuku tiket konser sing larang kuatku yo mung pamer karcis parkir pit motor" ("Sorry, dear... I can't afford to buy you an expensive concert ticket; I can afford only to show you a motor-bike parking ticket"). The writer of this humor meme informs the readers his inability to go to a concert whose ticket is expensive, and that he can only park his motorbike in the concert arena. The text is related to the maxim of quality in the Cooperative Principle, which is a text that is principle obedient to the maxim of quality because the expression is manifested in the chains of words of inability accompanied with the picture of a motorbike parking ticket.

The maxim of relevance in the Cooperative Principle requires that the contribution given should be relevant with the topic under discussion. The following Javanese humor meme is suitable with that maxim. 


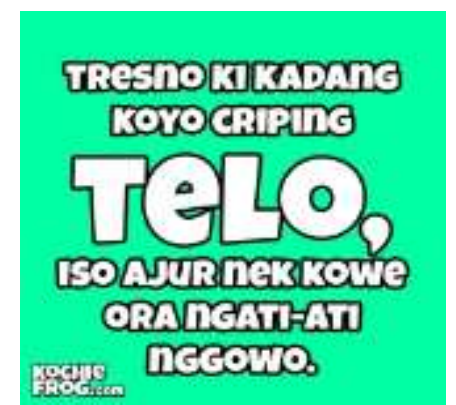

Figure 4. Meme principle-obedient to the maxim of relevance. Source: 9lucu.blogspot.com

The humor meme above contains the Javanese words "Tresno (tresna) ki kadang (kadhang) koyo (kaya) criping telo (tela), iso (isa) ajur nek kowe ora ngati-ati nggowo (nggawa) (Love is sometimes like cassava crackers, which can be crushed if you don't carry it carefully). The writer of the humor meme compares love with cassava crackers. At a glance, it is irrelevant but when both characteristics are viewed, cassava cracker and love are the same. Cassava crackers are the food and if they are not carried carefully and dropped by accident, they will break into pieces, and so is love, which must be cared or otherwise it will easily break. Therefore, the expression of the cassava cracker characteristics, which is relevant with love which is something easily broken if not taken carefully, is principle-obedient to the maxim of relevance

The maxim of manner in the Cooperative Principle requires that the contribution given should be expressed to the point, clear, unambiguous, not lengthy, and orderly. The following is a Javanese humor meme which is principle-obedient to the maxim of manner in the Cooperative Principle.

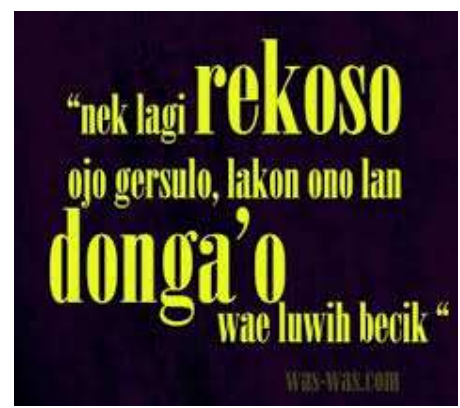

Figure 5. The meme principle-obedient to the maxim of manner. Source: https://www.google.com/search?q=meme+lucu+bahasa+jawa+sindiran\&rlz

The above humor meme reads, "Nek lagi rekoso (rekasa) ojo (aja) gersula, lakonono (lakonana) lan donga' o (dongaa) wae luwih becik" (When you have a problem, don't complain; solve it and pray - that is better). The writer of this humor meme suggests anyone having a problem, which is expressed using the linguistic unit nek lagi rekoso 'when you have a problem'. The suggestion for solving a problem is expressed to-the-point, clearly and orderly. The suggestion to those having a problem is that they need not complain because complaining cannot solve problems, but they are expected to live a life that Allah has determined and pray, and that is a better thing to do. This is expressed through the use of the expression "Ojo (aja) gersula, lakonono (lakonana) lan donga' o wae luwih becik” (Don't 
complain, live the life and pray; that is better). Of course, in the prayer we pray that God shows us the way to solve the problem that we have.

The Politeness Principle that has to be applied in social interactions using the language as the medium consists of the tact maxim, approbation maxim, generosity maxim, modesty maxim, agreement maxim, and sympathy maxim. The following are some humor memes which are principle-obedient to the maxims in the Politeness Principle.

The maxim of tact requires that the speaker should minimize the disadvantages of others or maximize the benefits to others. A humor meme that meets the principle obedience to the maxim of tact can be seen in the example below.

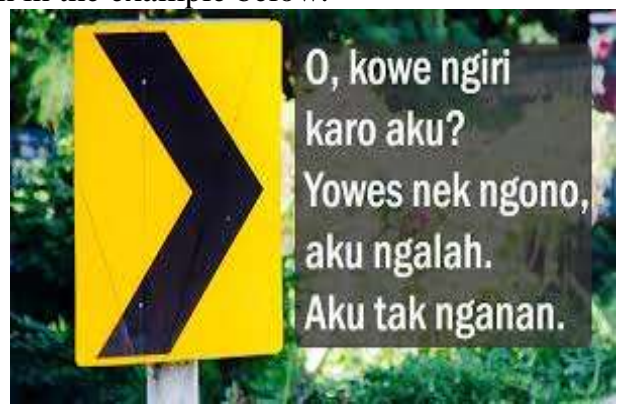

Figure 6. A humor meme which is obedient to the maxim of tact. Source: https://www.google.com/search?q=meme+lucu+bahasa+jawa+sindiran\&rlz

The above humor meme reads " $O$, kowe ngiri karo aku? Yowes nek ngono, aku ngalah. Aku tak nganan" ('Oh you are jealous of me, aren't you? Never mind, I give up. I'll do it my way"). The writer of this meme criticizes politely a jealous person using a humorous expression. When analysed, the expression "Yowes nek ngono, aku ngalah". (Never mind, I give up), the content of the text gives benefit to the interlocutor to be in the expected position, whereas the speaker takes another direction using the expression "Aku tak nganan" (I'll do it my way). The expression that minimizes the disadvantages of others is the expression that obeys the maxim of tact in the Politeness Principle.

The maxim of approbation in the Politeness Principle requires that in a communication process the speaker should maximize his/her own disadvantages or minimize his/her own benefits. The humor meme that is obedient to the maxim of approbation can be seen in the example below.

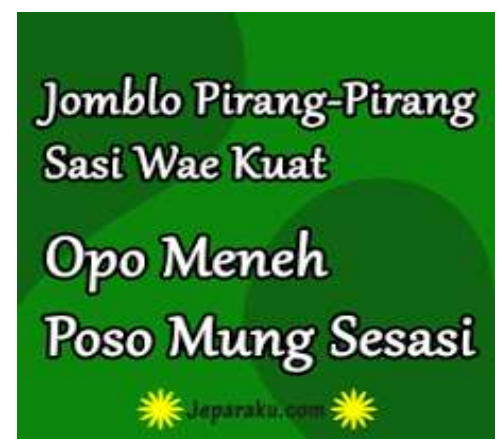

Figure 7. A humor meme which is obedient to the maxim of approbation. Source: https://www.google.com/search?q=meme+lucu+bahasa+jawa+sindiran\&rlz 
The humor meme above contains the expression "Jomblo pirang-pirang sasi wae kuat. Opo(apa) meneh poso (pasa) mung sesasi" (You can stand being a bachelor for months, let alone a one-month fasting). The writer of this meme expresses his tenacity to stand the inconvenient condition of being a bachelor for months. Therefore when he is fasting for only one month, he will definitely be able to do it easily. Being a bachelor is described as being inconvenient, so is fasting. When people have to stand hunger, thirst, and other desires, they are at a disadvantage. The meme of this kind can be considered as a discourse whose content is obedient to the maxim of approbation in the Politeness Principle.

The maxim of generosity in the Politeness Principle requires that a speaker should maximize the respect to others or minimize the blame on others. The humor meme that is obedient to that maxim can be seen in the example below.

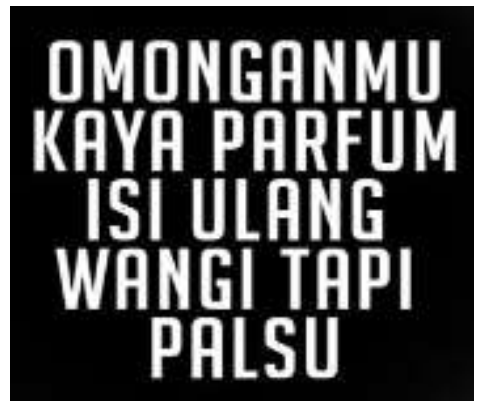

Figure 8. The humor meme which is obedient to the maxim of generosity. Source: https://ponselharian.com/200-gambar-dp-bbm-lucu-bahasa-jawa-terbaru-dan-lengkap

The humor meme above contains the expression "Omonganmu kaya parfum isi ulang wangi tapi palsu" (Your word is like a refilled perfume; it smells pleasant but it's fake). The writer of the meme expresses a phony expression by comparing it with a fake perfume with a pleasant smell. Although what is expressed is a false statement, which is something unpleasant, it is expressed through praises, by comparing it with a pleasant perfume. Therefore, it can be said that the text is obedient to the maxim of generosity in the Politeness Principle, because it maximizes the respect to others or minimizes the blame on others.

The maxim of modesty in the Politeness Principle requires that in communication a speaker should maximize the disrespect to himself/herself or minimize the respect to himself/herself. The following example reflects the meme that obeys the maxim of modesty.

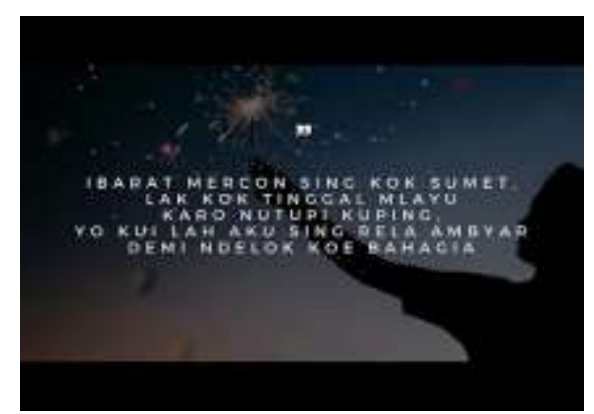

Figure 9. The humor meme which is obedient to the maxim of modesty. Source: https://ponselharian.com/200-gambar-dp-bbm-lucu-bahasa-jawa-terbaru-dan-lengkap 
The above humor meme contains the expression "Ibarat mercon sing kok sumet. Lak kok tinggal mlayu karo nutupi kuping. Yo kui lah aku sing rela ambyar demi ndelok koe (kowe) bahagia" (It is like when you lit a firecracker. You abandon it closing your ears. It's like me who's willing to be ruined looking at your being happy). The illustration of someone playing a firecracker is when the firecracker is lit and then the he runs away closing his ears in order not to be deaf, and when the firecracker has exploded and broken into pieces, the player is satisfied. A person who says that he is like a firecracker which is lit in order to make people happy shows that he does not respect himself much. He is always ready to be exploded/broken down in order to make others happy. The text containing such an element shows an attitude in line with the maxim of modesty.

The maxim of agreement requires that a speaker should maximize agreement with others or minimize disagreement. The humor meme that is obedient to the maxim of agreement can be seen in the example below.

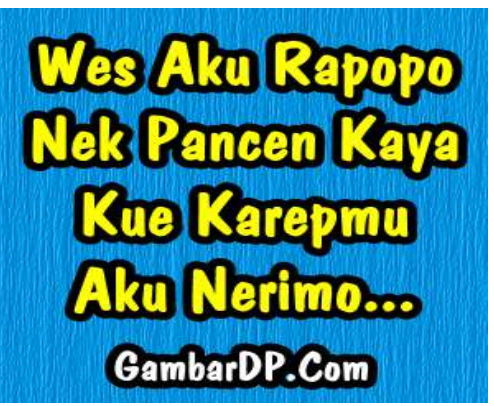

Figure 10. The humor meme which is obedient to the maxim of agreement. Source: https://ponselharian.com/200-gambar-dp-bbm-lucu-bahasa-jawa-terbaru-dan-lengkap

The above meme contains the expression "Wes aku rapopo(rapapa) nek pancen kaya kue (kuwi) karepmu aku nerima...(Never mind, I am fine. If that's what you really want it). The writer of this humor meme expresses that reality in the life in the society is not always what we have been expecting, so sometimes we have to accept what others want although it is not what we want. The Javanese expression for the willingness to accept what we do not want but others do is "Wes aku rapopo (rapapa) nek pancen kaya kue (kuwi) karepmu aku nerima... ..”.(Never mind, I am fine. If that's what you really want it). That expression shows the effort of the speaker to realize his agreement with the condition he is in. Therefore, the text contains the expression that obeys the maxim of agreement in the Politeness Principle.

The maxim of sympathy requires that a speaker should maximize sympathy or minimize antipathy for the interlocutor. The text that obeys the maxim of sympathy can be seen in the following example. 


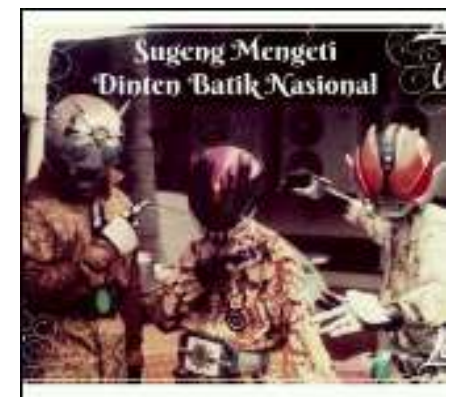

Figure 11. The humor meme which is obedient to the maxim of sympathy. Source: https://www.posbagus.com/inspirasi/status-galau-bahasa-jawal

The above humor meme contains the expression "Sugeng mengeti dinten batik nasional" (Happy national batik anniversary) in the context of the picture of the characters in Power Ranger, who are wearing batik costumes. The linguistic unit is the manifestation of the expression of sympathy for national batik anniversary, especially with the batik costumes worn by the characters of the child serial film Power Ranger. Usually, the costumes worn by the film characters are costumes as heroes with all types of attributes including red ranger, green rangers and many others. Therefore, it can be said that the humor meme is the discourse which obeys the maxim of sympathy in the Politeness Principle [27].

\section{CONCLUSIONS}

The Javanese language is used as a means of expressing a varieties of ideas in the life of Javanese community by considering pragmatic rules especially the Cooperative Principle and the Politeness Principle. The Javanese language is used, among others, to criticize or tease by way of not offending others, realizing it in humor discourses in the verbal written form expressed in memes. Although they are manifested in Javanese humor memes, they are still obedient to the maxims in the Cooperative Principle and Politeness Principle. Their principle obedience to the maxims in the Cooperative Principle includes: the contribution which is not more than required, the speech which is true and accompanied with evidence, the speech which uses relevant comparison, and the speech which is clear and orderly. The meme texts which obey the maxims in the Politeness Principle are realized in the texts containing the expressions that benefit others, the expressions that give others the chances to make their own choices, the expressions containing the readiness to control oneself, the expressions containing praises to others, the expressions comparing one with firecrackers, the expressions containing agreement with others, and the expressions containing congratulation.

\section{REFERENCES}

[1] B. E. Wiggins and G. B. Bowers, "Memes as genre: A structurational analysis of the memescape," New Media \& Society, vol. 17, no. 11, pp. 1886-1906, Dec. 2015.

[2] L. Laineste and P. Voolaid, "Laughing across borders: Intertextuality of internet memes," European Journal of Humour Research, vol. 4, no. 4, pp. 26-49, 2016.

[3] L. Laineste and E. Kalmre, "RUMOUR AND HUMOUR IN \#WhereIsPutin AND \#PutinUmer: GLOBAL MEDIA AND THE CULT OF PUTIN,” Folklore (Estonia), vol. 69, 2017.

[4] A. Listiorini, "Wacana Humor Dalam Meme Di Media Online Sebagai Potret 
Kehidupan Sebagian Masyarakat Indonesia,” Litera, vol. 16, no. 1, Jun. 2017.

[5] F. N. Anuar, F. Ahmad, and S. M. Salleh, "Meme Sebagai Seloka Persendaan dan Parodi: Impak Dimensi Sosiobudaya," Jurnal Komunikasi Malaysian Journal of Communication, vol. 34, no. 1, pp. 75-96, 2018.

[6] L. Grundlingh, "Memes as speech acts," Social Semiotics, vol. 28, no. 2, pp. 147-168, Mar. 2018.

[7] F. Yus, "Identity-Related Issues in Meme Communication," Internet Pragmatics, vol. 1, no. 1, 2018.

[8] L. Shifman, "Memes in a Digital World: Reconciling with a Conceptual Troublemaker," Journal of Computer-Mediated Communication, vol. 18, no. 3, pp. 362-377, Apr. 2013.

[9] M. Benaim, "From symbolic values to symbolic innovation: Internet-memes and innovation," Research Policy, vol. 47, no. 5, pp. 901-910, Jun. 2018.

[10] K. D. Wijayanti, "Meta Pesan dalam Perspektif Meme," in Seminar Nasional PRASASTI II Kajian Pragmatig dalam Berbagai Bidang, 2015, pp. 203-207.

[11] W. Lestari, "Irony Analysis of Memes on Instagram Social Media," PIONEER: Journal of Language and Literature, vol. 10, no. 2, pp. 114-123, Jan. 2019.

[12] H. Luvytasari, "Meme Instagram Dagelan Kajian Sosiolinguistik," Universitas Gadjah Mada, 2015.

[13] T. J. Blank, "Folklore and the Internet: The Challenge of an Ephemeral Landscape," Humanities, vol. 7, no. 2, p. 50, 2018.

[14] G. de Seta, "Digital Folklore," in Second International Handbook of Internet Research, Dordrecht: Springer Netherlands, 2019, pp. 1-17.

[15] S. Allifiansyah, "Kaum Muda, Meme, dan Demokrasi Digital di Indonesia," Jurnal ILMU KOMUNIKASI, vol. 13, no. 2, p. 151, Jan. 2017.

[16] E. Oring, "Memetics and Folkloristics," Western Folklore, vol. 73, no. 4, 2014.

[17] E. Chattoe, "Virtual Urban Legends: Investigating The Ecology Of The World Wide Web," In A Memetic Compendium, R. Finkelstein, Ed. Maryland: Robotic Technology Inc, 2008

[18] Z. Denysyuk, "Internet memes as a means of post-folklore communication," National Academy of Managerial Staff of Culture and Arts Herald, vol. 0, no. 2, 2017.

[19] D. Bebic and M. Volarevic, "Do not mess with a meme: the use of viral content in communicating politics," Comunicación y Sociedad, vol. 31, no. 3, pp. 43-56, 2018.

[20] G. K. Aguilar, H. A. Campbell, M. Stanley, and E. Taylor, "Communicating mixed messages about religion through internet memes," Information, Communication \& Society, vol. 20, no. 10, pp. 1498-1520, Oct. 2017.

[21] H. E. Huntington, "Subversive Memes: Internet Memes as a Form of Visual Rhetoric," AoIR Selected Papers of Internet Research, vol. 14, 2013.

[22] C. Xie and B. Li, "Politeness, Language and Memes," Journal of Fujian Normal University (Philosophy and Social Sciences Edition), vol. 3, 2006.

[23] A. Sharag-Eldin, X. Ye, and B. Spitzberg, "Multilevel model of meme diffusion of fracking through Twitter," Chinese Sociological Dialogue 2018, Vol. 3(1) 17-43, vol. 3, no. 1, pp. 17-43, 2018.

[24] I. G. A. R. S. Dewi, I. N. Suandi, and N. M. R. Wisudariani, "Jenis, Bentuk, Dan Fungsi Tindak Tutur Meme Comic Pada Facebook," Jurnal Pendidikan Bahasa dan Sastra Indonesia Undiksha, vol. 5, no. 3, Nov. 2016.

[25] H. Grice, "Logic and Conversation," in Syntax and Semantic: Spech Act, New york: Academic Press. 
[26] I. D. P. Wijana, Dasar-dasar Pragmatik. Yogyakarta: ANDI, 1996.

[27] K. Saddhono, N. E. Wardani, and C. Ulya. "Sociopragmatic approach on discourse structure of friday prayer's sermon in java and madura island." J. of Lang and Lit, vol. 6 no. 1 pp 26-29, 2015. 